\title{
İç Göçe Maruz Kalmış Ortaokul Öğrencilerinin Eğitimde Yaşadıkları Problemler
} (Diyarbakır İli Örneği)*

\section{Bünyamin HAN**, Rasim TÖSTEN*** ve Yunus Emre AVCI ${ }^{* * * *}$}

Öz: Bu araştırmanın amacı, okul yöneticileri ve öğretmenlerin bakış açısıyla iç göçten etkilenen okullardaki öğrencilerin eğitim sürecinde karşılaştıkları sorunları belirlemek ve bu sorunların çözümlerine yönelik öneriler sunmaktır. Bu amaca yönelik olarak Diyarbakır il merkezinde yer alan ve iç göç alarak öğrenci sayısı artan kamu ortaokullarında görev yapan okul yöneticisi ve öğretmenlerin görüşlerine başvurulmuştur. Çalışma, nitel araştırma yöntemi kullanılarak gerçekleştirilmiştir. Bu bağlamda araştırmanın temel amacına ulaşabilmek için iç göç ile öğrenci sayısı hızlı bir şekilde artan kamu ortaokullarının yönetici ve öğretmenlerinden detaylı veri toplamak için yarı yapılandırılmış görüşme formu kullanılarak görüşmeler yapılmıştır. Görüşme formu soruları öğretmen ve okul yöneticileri ile yapılan ön görüşme ile saptanıp alandaki akademisyenlerce geliştirilmiş ve son hali verildikten sonra 2 okul müdürü, 2 müdür yardımcısı ve 13 öğretmene uygulanmıştır. Elde edilen veriler betimsel analiz tekniği ile analiz edilerek öğretmen ve okul yöneticileri açısından iç göçle gelen öğrencilerin eğitim sorunları ortaya konulmuştur. Araştırma sonuçlarına göre; iç göçle yer değiştiren öğrenciler uyum sorunları yaşamaktadırlar, akademik başarıları düşük düzeydedir, velileri okula ilgisizdir, okulda şiddet eğilimi göstermektedirler ve maddi açıdan problemler yaşamaktadırlar. Araştırma sonucunda bu sorunların çözümü için öneriler sunulmuştur.

Anahtar Kelimeler: Diyarbakır, iç göç, eğitim sorunları

\footnotetext{
** Bu çalışmanın bir kısmı 21-24 Nisan 2016 tarihinde Antalya'da düzenlenen 25. Ulusal Eğitim Bilimleri Kongresi'nde sözlü bildiri olarak sunulmuştur.

** Arş. Gör. Dr., Dicle Üniversitesi, Eğitim Bilimleri Bölümü, bunyaminhan@gmail.com ORCID: 0000-0003$\underline{0204-5686}$

*** Dr. Öğr. Üyesi., Siirt Üniversitesi, BESYO Bölümü. rasimtosten@hotmail.com ORCID: 0000-0001-51357286

**** Dr. Öğr. Üyesi., Siirt Üniversitesi, Eğitim Bilimleri Bölümü. yunusavci027@hotmail.com ORCID: 0000$\underline{0002-1361-1463}$

Gönderim:22.02.2019 Kabul:26.09.2019 Kayın: 20.10.2019
}




\title{
Educational Problems of Secondary School Students Who Exposed to Internal Migration (Case of Diyarbakır Province)
}

\begin{abstract}
The aim of this research is to identify the problems of the students who are exposed to internal migration in the educational process according to the views of teachers and school administrators and to present suggestions related to them. For this purpose, it was asked the views of administrators and teachers working in public secondary schools, where the number of students with internal migration has increased, in the central districts of Diyarbakir province. The research is conducted by using qualitatively research design. Therefore, in order to achieve the main objective of the research, the interviews were made to collect detailed data from the teachers and administrators who are in the public schools whose number of students increased quickly. In interviews, semi structured interview forms were used. The questions in the interview forms were determined first by a preliminary discussion with the teachers and administrators then were developed by academicians and then were applied to 2 school principals, 2 vice-principals and 13 teachers. The data was analyzed by descriptive analysis technique and the educational problems were detected according to the opinions of teachers. According to the research results; the students who replaced because of internal migration were found to have adaptation problems, having low academic success, having unconcerned parents, having violence tendencies and having financial problems. Some suggestions were set forth for the solution of these problems.
\end{abstract}

Keywords: Diyarbakır, internal migration, education problems

\section{Giriş}

İnsanların yer değiştirme hareketi olarak tanımlanabilen göç, bir kural olarak insanın yaşadığı mekânın ve çevrenin koşulları onun yaşamını zorlamaya başladığında ortaya çıkmaktadır (Akokpari, 1998; Richmond, 1994). Göçü bireyin isteğine bağlı olarak ya da zorunlu olarak ikiye ayırmak mümkündür (Gürel, 2001). Zorunlu göç; terör, afet, çöküş, güvenlik tedbiri ve sair durumlardan dolayı istemsiz şekilde yer değiştirmeyi ifade eder. İsteğe bağlı göç ise bireyin kendi isteği bulunduğu yeri değiştirmesini ifade eder. Yine göç olgusunu bir ülke içinde gerçekleşen iç göç veya ya da ülkeler arası gerçekleşen dış göç şeklinde de ifade etmek mümkündür. İç göçün başlamasını gerekli kılacak etmenler parçalanmış topraklar, nüfus 
artışı, tarım tekniklerinin gelişmesi, sanayileşme, ulaşım ve huzursuz ortamlar olarak ifade etmek mümkündür (Üçdoğruk, 2013).

Ülkemizde 1950'li yıllardan itibaren kırsal kesimlerden kent merkezlerine, az gelişmiş bölgelerden gelişmiş bölgelere doğru bir göç hareketi yaşanmaktadır (Bülbül ve Köse, 2010; Erkan ve Bağlı, 2005). Özellikle köyden kente bu yoğun göç hareketleri son yıllarda hızlanmıştır (Güreşci, 2010). Göçün kaynağına bakıldığında; gelir düzeyi ve işsizlik oranı, sanayileşme düzeyi, sağl1k, eğitim kalitesi ve terör gibi etkenlerin yer aldığı görülmektedir (Gür ve Ural, 2004). Özellikle Doğu ve Güneydoğu Anadolu Bölgesi'ndeki terör sorunları bu durumu tetikleyen önemli bir faktördür (Aksoy, 2006).

Güneydoğu Anadolu Bölgesinde yer alan ve sosyo-politik açıdan önemli bir il olan Diyarbakır, zaman zaman artan terör olayları ve bazı ilçelerinde ilan edilen sokağa çıkma yasakları ile ciddi bir iç göçe maruz kalmaktadır. Bu göç olayları sıradan bir yer değiştirme olmayıp olumsuz etkilerini ekonomik, sosyal, kültürel ve eğitim alanında da hissettirmeye başlamıştır. Eğitim, bir süreçtir ve bu süreçte ortaya çıkan beklenmedik olaylar eğitim sürecinde oldukça yıkıcı neticelere sebep olabilmektedir. Eğitimde meydana gelen olumsuz bir durumun etkileri zaman içinde ve değişik şekillerde kendini gösterebilmektedir (Garipağaoğlu, 2001). Eğitim alanında göçle ilgili meydana gelen problemlerin gün geçtikçe artıp kökleştiği (Gedikoğlu, 2005) düşünüldügünde, bu problemlerin eğitim paydaşlarınca incelenerek zamanında tespit edilmesi gerektiği düşünülmektedir. Bu şekilde göçe maruz kalan öğrencilerin karşılaştıkları eğitimsel sorunlara çözüm önerileri sunulabilir. Araştırma bulguları 1şı̆̆ında ortaya konulan öneriler kalıcı ve etkili bir çözüm için oldukça önem taşımaktadır.

Diyarbakır ili son yıllarda yaşanan ve özellikle 2016 yılından itibaren şehir içinde birçok mahallede kendini gösteren terör olaylarından oldukça fazla etkilenmiştir. Olayların sıkça tekrarlandığı mahallelerde ikamet eden vatandaşlar, bu bölgeleri terk etmek zorunda kalmışlardır. Sokağa çıkma yasaklarının ilan edilmesiyle zorunlu hale gelen iç göç, il merkezinde birçok okulun öğrenci sayısını sıfıra indirdiği gibi birçok okulun da öğrenci sayısını oldukça artırmıştır. İç göç ile yer değiştiren ailelerin çocuklarının kayıt oldukları okullar, bu beklenmedik öğrenci artışı karşısında eğitimin aksamaması için tedbir almak durumunda kalmışlardır. Aksi halde gelen öğrenciler eğitime entegre olmada başarısız olursa, hem gelen öğrenciler hem de mevcut eğitim faaliyetleri zarar görecektir.

Bu amaçla, Diyarbakır merkez ilçelerinde yaşanmakta olan yoğun iç göçe maruz kalan öğrencilerin karşılaştıkları eğitimsel sorunların tespitinde okul yöneticileri ve öğretmenleri başta olmak üzere okulun tüm bileşenlerinin gözlemleri oldukça önemlidir. Uygulamanın 
içinde olan ve bu sorunlarla sıkça karşılaşan öğretmen ve okul yöneticilerinin görüşlerine başvurularak sorunların doğru ve tam olarak saptanması gerekmektedir. Böylece bilimsel çözüm önerileri ortaya konularak eğitim sürecinde oluşabilecek aksaklıkların önüne geçilebilir. İşte bu araştırmanın bu konuda önemli bir etkisinin olacağı düşünülmektedir.

\section{Araştırmanın Amacı}

$\mathrm{Bu}$ araştırmanın amacı, Diyarbakır İli merkez ilçelerinde yer alan ve iç göçle öğrenci sayısı artan kamu ortaokullarında görev yapan öğretmen ve okul yöneticilerinin görüşlerine dayalı olarak göçle yer değiştiren öğrencilerin eğitim sürecinde karşılaştıkları sorunları belirleyerek, bu sorunlara yönelik çözüm önerileri geliştirmektir. Bu kapsamda aşağıdaki soruların yanıtları aranmıştır:

1. İç Göçle Yer Değiştiren (İGYD) öğrencilerin göç etme nedeni nedir?

2. İGYD öğrencilerin çevreye (sınıf, okul, mahalle) uyumlarında karşılaşılan sorunlar var midir? Varsa nelerdir?

3. İGYD öğrencilerin eğitsel başarıları nasıldır? Bu süreçte karşılaşılan güçlükler nelerdir?

4. İGYD öğrenci velilerinin eğitim duyarlılığında sorunlar var mıdır? Varsa nelerdir?

5. İGYD öğrencilerin şiddet eğilimleri var mıdır? Varsa ne tür davranışlar sergilemektedirler?

6. İGYD öğrencilerin ekonomi kaynaklı sorunlarının eğitime yansımaları nasıldır?

\section{Yöntem}

Bu bölümde araştırma modeli, evren ve örneklem, verilerin toplanması, analizi, geçerlik ve güvenirliğe ilişkin bilgiler verilmiştir.

\subsection{Araştırmanın Modeli}

$\mathrm{Bu}$ çalışma, nitel araştırma yöntemi kullanılarak gerçekleştirilmiştir. Yıldırım ve Şimşek (2005) nitel araştırmayı "gözlem, görüşme ve doküman analizi gibi nitel veri toplama yöntemlerinin kullanıldığı, algıların ve olayların doğal ortamda gerçekçi ve bütüncül bir biçimde ortaya konmasına yönelik nitel bir sürecin izlendiği araştırma" türü olarak tanımlamaktadır. Bu araştırmada iç göçle yer değiştiren öğrencilerin eğitimsel sorunlarının doğal ortamda gerçekçi ve bütüncül bir biçimde, detaylı olarak ortaya konulması amaçlandığından nitel araştırma yöntemi kullanılmıştır.

\subsection{Veri Toplama Aracı}


$\mathrm{Bu}$ araştırmanın verileri, yarı yapılandırılmış görüşme tekniğine uygun olarak hazırlanan görüşme formu ile toplanmıştır. Yarı yapılandırılmış görüşme tekniğinde araştırmacı deneğe sormak istediği soruları önceden hazırlar. Hazırlanan bu sorular her katılımcıya belli bir sistem çerçevesinde sorulur. Katılımcılardan her katılımcıya aynı soruların sorulduğu görüşmede aynı cevapları vermemelerini sağlamak amacıyla ayrıntıya inebilmeleri sağlanır (Altunışık, Coşkun, Yıldırım ve Bayraktaroğlu, 2001). Bu amaçla, araştırmacılar tarafından alanyazına dayalı olarak hazırlanan görüşme formunda; öğrencilerin göç etme nedeni, çevreye (sınıf, okul, mahalle) uyumlarında karşılaşılan sorunlar, akademik başarıları, öğrenci velilerinin eğitim duyarlılığı, öğrencilerin şiddet eğilimleri, ekonomik durumlarından kaynaklanan problemlere yönelik sorular yer almaktadır.

\section{3.Çalışma Grubu}

Araştırmanın çalışma gurubunu, 2016 yılında Diyarbakır il merkezinde yer alan ortaokullarda görevli 13 öğretmen, 2 müdür yardımcısı ve 2 okul müdürü oluşturmaktadır. Araştırmanın çalışma grubunun oluşturulmasında amaçlı örnekleme tekniklerinden ölçüt örnekleme kullanılmıştır. İç göçle öğrenci sayısı hızla artmış olan okullar ölçüt olarak seçilerek araştırma sınırlandırılmıştır. Araştırmada bu ölçütü sağlayan ve öğrenci sayısı en fazla artan ilk 4 okul belirlenmiştir. Bu okullarda görev yapan ve görüşmeyi gönüllü olarak kabul eden okul yöneticileri ve öğretmenler ile görüşmeler gerçekleştirilmiştir.

Araştırmada yer alan katılımcıların bazı kişisel özellikleri şu şekildedir: Toplam 17 katılımcının 2'si okul müdürü, 2'si müdür yardımcısı ve 13'ü ise öğretmendir. Cinsiyet bakımından 7'si erkek, 10'u ise kadındır. Katılımcıların 12'si Yenişehir, 5'i ise Sur ilçesindeki okullarda görev yapmaktadırlar.

\subsection{Verilerin Toplanması ve Analizi}

Araştırma kapsamında Diyarbakır il merkezinde bulunan ve iç göçle öğrenci sayısı artmış olan ortaokullara gidilerek okul yöneticileri ile araştırmaya yönelik görüşmelerin yapılması konusunda izlenecek yöntemler görüşülmüştür. Öğretmenler için uygun olan zaman belirlendikten sonra okulda seçilen sessiz bir ortamda birebir görüşmeler yapılmıştır. Görüşmelerde yarı yapılandırılmış görüşme formları katılımcılar tarafından doldurulmuştur.

Verilerin analizi nitel veri analizi aşamaları gözetilerek yapılmıştır. Miles ve Huberman'ın (1994), belirttiği gibi nitel veri analizi sürecinde birtakım aşamalardan geçilir. Elde edilen bulguları düzenlenmiş ve yorumlanmış bir biçimde okuyucuya sunmak için; elde edilen veriler mantıklı ve anlaşılır biçimde betimlenir, yapılan bu betimlemeler yorumlanır, neden-sonuç ilişkileri irdelenir ve birtakım sonuçlara ulaşılır ve araştırmacının yapacağı 
yorumlar arasında ortaya çıkan temalar ilişkilendirilir, anlamlandırılır ve ileriye yönelik tahminlerde bulunulur (Yıldırım ve Şimşek, 2005). Bu araştırmada bu süreçler göz önünde bulundurularak, betimsel analiz tekniği kullanılmıştır. Betimsel analiz; elde edilen verilerin daha önceden belirlenen temalara göre özetlenip yorumlandığı, görüşülen bireylerin görüşlerinin çarpıcı bir biçimde yansıtmak amacıyla sık sık doğrudan alıntıların kullanıldığı ve elde edilen sonuçların neden- sonuç ilişkileri çerçevesinde yorumlandığı analiz tekniğidir. Bu araştırmada görüşme yapılan okul yöneticileri ve öğretmenlerden elde edilen veriler betimlenerek yorumlanmıştır. Neden sonuç ilişkileri irdelenerek, okuyucunun rahatça görebileceği özet bilgilere ulaşılmaya çalışılmıştır. Verilerin kodlanmasında katılımcıların tümü öğretmen olarak değerlendirilip Ö1, Ö2 şeklinde kısaltılarak verilmiştir.

\subsection{Geçerlik ve Güvenirlik}

Veri toplama aracı ve analiz sürecinin geçerlik ve güvenirliği konusunda öncelikle veri toplamak için kullanılan görüşme formunun hazırlanması için medya ve ilgili literatür taranmış, uzman kontrolünden geçtikten sonra öğretmen ve okul yöneticileri ile yapılan ön görüşmelerle form son haline kavuşturulmuştur. Veriler, katılımcılar tarafından doldurulan görüşme formları aracılığı ile birebir toplanmış ve kayıt altına alınmıştır. Araştırmanın geçerliğini artırmak için katılımcı teyidi alınmıştır. Yine verilerin raporlaştırılmasında katılımcıların ifadelerinden doğrudan alıntılar yapılarak görüşülen bireylerin görüşleri doğru bir biçimde yansıtılmaya çalışılmıştır.

Araştırma verileri betimsel analize tabi tutulmuş ve uygulama sonrasında, öğretmenlerin açık uçlu sorulara verdikleri yanıtlar hem araştırmacılar hem de araştırmalar dışında bir öğretim üyesi (Prof. Dr., Dicle Üniversitesi, Eğitim Fakültesi, Eğitim Bilimleri Bölümünde görev yapan) tarafından ayrı ayrı incelenmiştir. Elde edilen veriler ışı̆̆ında oluşturulan kodlar kapsamında "görüş birliği” ve "görüş ayrılığı" olan konular tartışılmış ve gerekli düzenlemeler yapılmıştır. Araştırmanın güvenilirlik hesaplaması için Miles ve Huberman'ın (1994) önerdiği güvenirlik formülü kullanılmıştır. Güvenirlik = Görüş Birliği/(Görüş Birliği + Görüş Ayrılığı). Hesaplama sonucunda araştırmanın güvenirliği \% 88 olarak hesaplanmıştır. Güvenirlik hesaplarının \%70'in üzerinde çıkması, araştırma için güvenilir kabul edilmektedir (Miles ve Huberman, 1994). Burada elde edilen sonuç, araştırma için güvenilir kabul edilmiştir.

\section{Bulgular}

Araştırma verilerinin analiz edilmesiyle ulaşılan bulgular aşağıda sırasıyla açıklanmıştır. 


\section{1. İç Göçle Yer Değiştiren (İGYD) Öğrencilerin Göç Etme Nedeni Nedir?}

Araştırma kapsamında görüşme yapılan okul yöneticileri ve öğretmenlere "İç göçle yer değiştiren öğrencilerin göç etme nedeni nedir?” sorusu yöneltilmiştir. Katılımcıların tamamı öğrencilerin göç etme nedeninin “Diyarbakır'da yaşanan terör olayları” olduğunu ifade etmişlerdir.

\section{2. İç Göçle Yer Değiştiren Öğrencilerin Uyum Sorunları}

Araştırma kapsamında görüşme yapılan okul yöneticileri ve öğretmenlere "İç göçle yer değiştiren öğrencilerin çevrelerine uyumlarında karşılaşılan sorunlar var mıdır? Varsa nelerdir?" sorusu yöneltilmiştir. Katılımcılar, öğrencilerin uyum problemlerini sınıf, okul ve çevrede karşılaşılan problemler olarak 3 grupta farklı örneklerle ifade etmişlerdir. Katılımcılar tarafından verilen cevaplardan ulaşılan kategoriler aşağıdaki Tablo 1' de gösterilmiştir.

Tablo 1. İç Göçle Yer Değiştiren Öğrencilerin Uyum Sorunları

\begin{tabular}{ll}
\hline Kodlar & $\boldsymbol{f}$ \\
\hline Uyum sorunu olmadığını düşünenler & $\mathbf{2}$ \\
\hline Uyum sorunu olduğunu düşünen & $\mathbf{1 5}$ \\
\hline Sınıf İçi Uyum Problemleri & 13 \\
\hline Okul İi Uyum Problemleri & 12 \\
\hline Mahalli Uyum Problemleri & 6 \\
\hline
\end{tabular}

Tablo 1'de görüldüğü gibi, görüşme yapılan öğretmenlerin 15'i çeşitli uyum problemlerinden bahsederken, 2'si ise öğrencilerin uyum problemini gözlemlemediğini ifade etmiştir. Öğretmenlerden 13'ü sınıf içi uyum problemlerine, 12'si öğrencilerin okuldaki uyum problemlerine, 6'sı ise öğrencilerinin mahalledeki uyum problemlerine değinmiştir.

İç göçle yer değiştiren öğrencilerin sınıf ortamında karşılaştıkları problemleri ortaya koyan öğretmenlerden bazılarının ifadeleri şu şekildedir:

Sinıf içinde çekingen ve potansiyelini gösteremeyen ögrenciler var. Uyum problemi yaşıyorlar ve kaygll bir ruh halleri var (Ö. 10). Sinıf atmosferine adapte olmak, okul, ögretmen ve arkadaş adaptasyonunda göç eden ögrencilerin \%90'ını sıkıntı yaşamaktalar (Ö. 3). Sinıf ortamındaki diğer ögrencilere uyum sağlamada güçlük çektiler. Entegre olamadılar (Ö. 6). Arkadaşlarına uyum sağlayamama, ders uyumunda güçlük, içe kapanma eğilimi (Ö. 7). Sınıfta dikkatsiz ve sessizdirler (Ö. 15).

Öğrencilerin okulda karşılaştıkları problemleri ifade eden öğretmenlerin bazı ifadelerine şu örnekler verilebilir:

Yalnızlık ve yabancılaşma içe kapanma olur bazı öğrencilerde, okulda uyumsuzluk veya hırçın davranışlarda bulunma, huzur ve güvende bulunma isteği, ĕger bunlar yoksa korku yaşamaları (Ö. 2). Eski okulundaki arkadaşlarından ayrı olduklarından yeni ortamda kendilerini bu okula ait hissedemediler (Ö. 6). Okul kurallarına uymada güçlük, depresyon hali (Okulumuzun bütünleştirici tavrı daha ăğr travmaları engelledi) (Ö. 7). Okul kurallarına uymuyorlar. Okul camlarını kırma, tuvaletleri kirli bırakma ve düzensizlik var (Ö. 15). 
İç göçle yer değiştiren öğrencilerin yaşadıkları çevrede de bazı problemlerini gözlemleyen öğretmenler, bu problemleri şu ifadelerle belirtmişlerdir:

Göçten dolayı evleri daha uzak bölgelerde yaşayan ailelerin çocukları okula gidiş geliş noktasında sıkıntı yaşamakta (Ö. 3). Mahallede daha çok sıkıntı yaşamaktadırlar. Çünkü geldikleri mahallenin ortamını bulamamakla beraber o yaşantılarını tekrar bulabilmenin zorluğunu çekmektedirler (Ö. 6). Semt değişikliğinden kaynaklt servise binme durumunu çok yıpratıcı bir şekilde yaşadık (Ö. 4). Yeni komşularla oryantasyon sorunu oluşuyor (Ö. 5).

\section{3. İç Göçle Yer Değiştiren Öğrencilerin Akademik Başarıları}

Araştırma kapsamında görüşme yapılan okul yöneticileri ve öğretmenlere "İç göçle yer değiştiren öğrencilerin akademik başarıları nasıldır? Bu süreçte karşılaşılan güçlükler nelerdir?” sorusu sorulmuştur. Katılımcıların iç göçle yer değiştiren öğrencilerin akademik başarılarına ilişkin görüşleri Tablo 2'de verilmiştir.

Tablo 2. İGYD Öğrenci Akademik Başarıları ve Karşılaşılan Problemler

\begin{tabular}{ll}
\hline Kodlar & $\boldsymbol{f}$ \\
\hline Orta veya iyi düzeyde & 3 \\
\hline Düşük düzeyde & 14 \\
\hline Toplam & $\mathbf{1 7}$ \\
\hline
\end{tabular}

Tablo 2'de görüldüğü gibi, öğretmenlerin 14'ü bu öğrencilerin akademik başarılarının düşük olduğunu, 3’ü ise orta veya iyi düzeyde olduğunu ifade etmişlerdir.

Öğretmenlerin 2'si öğrencilerin düşük başarılarına vurgu yapmış, karşılaşılan güçlüklerden bahsetmemiştir. Öğretmenlerin 12'si düşük başarıya ve karşılaşılan farklı güçlüklere değinmişlerdir. Görüşme yapılan öğretmenlerin görüşlerine şu örnekler verilebilir:

Karşılaştıkları güçlüklere bağlı olarak motivasyonları düşüktür. Öğrencileri tekrar güdülemek konusunda zorluklar yaşanmaktadır (Ö. 1). Yeni geldikleri yerlerin şartlarıyla orantılı olarak algıda zayıflık ve konsantrasyon bozukluğu çokça devamsızlık yapılması gibi durumlara rastlanmaktadır (Ö. 2). Birçok sıkıntıyla bir anda baş etme güçlügü yaşadıkları için rehberlik-danışmanlık yardımı almaları gerektiğini düşünüyorum (Ö. 3). Öğrenciyi çektiği sıkıntılardan sonra yeni ortama alıştırmak güç olduğundan ĕgitim-öğretim pek de olması gerektiği gibi ilerlemiyor (Ö. 5). Değişik seviyede öğrenciler var fakat uzun süre ĕgitimde verilen ara yüzünden işleyemedikleri konuların telafisini tam olarak yapamadık ve geri kaldılar (Ö. 7). Derslere katılımları düşüktür. Ödev yapmıyorlar. Yaşadıkları travmadan kurtulmaya çalışıyorlar (Ö. 13). Çok zeki olanlar bile bir ya da iki adım olması gerektiği yerden gerideler. Olumsuz davranışlar sergiliyorlar. Bunun dışında bizim öğrencilerimiz de bu çatışma ortamının ya içinde ya da yakınında olduğu için onlarda da buna benzer davranışlar ve panik havast var (Ö. 14).

Görüşme yapılan 3 öğretmen ise iç göçle yer değiştiren öğrencilerin akademik başarı düzeylerinin orta veya iyi düzeyde olduklarını belirtmişlerdir. Bu görüşlere şu örnekler verilebilir: 
Bu öğrenciler içerisinde de çok başarılı olan da var. Ĕ̆itim seviyeleri iyi sayılır (Ö. 8). Öğrenciler var olan ögrencilerle aynı başarıyı gösteriyor. Hatta bazı ögrencilerin okul değiştirmeleri başarılarını kamçılamıştır (Ö. 9).

\section{4. İç Göçle Yer Değiştiren Öğrenci Velilerinin Eğitim Duyarlılığı ve Karşılaşılan}

\section{Sorunlar}

Araştırma kapsamında görüşme yapılan okul yöneticileri ve öğretmenler "İç göçle yer değiştiren öğrenci velilerinin eğitim duyarlılığında sorun var mıdır? Varsa nasıldır?” sorusuna çeşitli yanıtlar vermişlerdir. Görüşme yapılan 17 öğretmenden 1'i velilerin eğitim duyarlılığ1 ile ilgili herhangi bir sorun olmadığını ifade ederken 16'sı sorun olduğunu belirtip farklı sorunlara değinmişlerdir. Öğretmenlerin bu konudaki görüşleri Tablo 3’te verilmiştir.

Tablo 3. Öğrenci Velilerinin Eğitim Duyarlılığı ve Karşılaşılan Sorunlar

\begin{tabular}{ll}
\hline Kodlar & $f$ \\
\hline Eğitim duyarlılı̆̆ı yüksek, sorun yok & 1 \\
\hline Olumsuz koşullar sebebiyle düşük duyarlılık & 12 \\
\hline Babaların ilgisizliği ve ilgilenen annelerin bilgisizliği & 4 \\
\hline Toplam & $\mathbf{1 7}$ \\
\hline
\end{tabular}

Tablo 3'de görüldüğü gibi öğretmenlerden biri dışında tamamı velilerin eğitim duyarlılığının yeterli olmadığını ifade etmişler. Bu duyarsızlığa kaynak olarak içinde bulundukları olumsuz koşullar, babaların ilgisizliği ve ilgilenen annelerin bilgisizliğinin sebep olduğu farklı durumlara değinmişlerdir. Bu şekilde görüş bildiren öğretmenlerin bazı ifadeleri şu şekildedir:

Veliler yaşadıkları göçün getirdiği sıkıntılar nedeniyle ögrencileri geri plana bırakmış durumda, öğrencilerin başarısı ve okula uyum noktasında veli-öğretmen irtibatı zaruri bir gereklilikken velilerimizin ilgisizliği yı̆̆ın halinde problem getiriyor (Ö. 3). Velilerle tanışamadık bile, varın gerisini siz düşünün (Ö. 10). Duyarlılık çok zayıf, ilgisizlik var. Yaşanılan zorluklar nedeniyle çocuklar ihmal ediliyor (Ö. 12). Dışarıdaki herhangi bir panik havasında veliler hemen ögrencilerini okuldan almaya geliyorlar. Veliler yaşadıkları maddi sorunlardan dolayı öğrencilerin okul ihtiyaçlarını gidermekte zorlaniyorlar ya da gideremiyorlar. Göçten dolayı taşındıkları yerlerde kabul edilmelerinde zorluklar yaşadı̆̆ için çocuklarının dersleri için komşularından yardım isteyemiyorlar (Ö. 14). Babalar daha çok ekonomik sorunlarla ilgilenmesi nedeniyle genelde anneler ögrenciyle ilgilenmeye çalışlyor fakat onlarda babalardan daha az ĕ̆itim almış ve hatta birçoğu okumayı bilmiyorlar. Sözün özü babalarda ilgisizlik annelerde bilgisizlik var (Ö. 17).

\section{5. İç Göçle Yer Değiştiren Öğrencilerin Şiddet Eğilim Durumları}

Öğretmenlere "İç göçle yer değiştiren öğrencilerin şiddet eğilimleri var mıdır? Varsa ne tür davranışlar sergilemektedirler?” sorusu sorulmuştur. Alınan cevaplar analiz edilerek bu konudaki öğretmen görüşleri Tablo 4'te ifade edilmiştir.

Tablo 4. İç Göçle Yer Değiştiren Öğrencilerin Şiddet Eğilim durumları 


\begin{tabular}{ll}
\hline Kodlar & $\boldsymbol{f}$ \\
\hline Şiddet eğilimleri yoktur & 3 \\
\hline Şiddet eğilimlerini olumsuz davranışlarla gösteriyorlar & 14 \\
\hline Toplam & $\mathbf{1 7}$ \\
\hline
\end{tabular}

Tablo 4’te görüldüğü gibi araştırmada görüşme yapılan öğretmenlerden 3'ü göçle gelen öğrencilerin dikkate değer bir şiddet eğilimlerinin olmadığını beyan ederken 14'ü ise bu öğrencilerin şiddet eğilimlerinin olduğunu ve bu durumu çeşitli olumsuz davranışlarla gösterdiklerini belirtmişlerdir. Bu şekilde düşünen öğretmen görüşlerine şu örnekler verilebilir:

Şiddet eğilimleri vardır. Sur içerisinde yaşanan tüm olayları kendi aralarında hikayeleştirerek, özenme ĕgilimi görülmektedir. Sınıf arkadaşlarılla kavga ve davranış bozukluğu sergiledikleri görülmektedir (Ö. 1). Evet, hırçın davranışlarda bulunma. Yüksek sesle konuşma ve darp etme şeklinde kendini gösteriyor (Ö.2). Çok yoğun bir şekilde var. Ve bu bütün sınıfı tahrik edici kızıştırıcı bir etki yapıyor. Sevgi saygı eksikliği var okula, öğretmene ve arkadaşlarına karşı. Bunlar olmadan nasıl davrandıklarını siz düşünün (Ö. 3). Var, oyunlar bile şiddet üzerine kurulu olduğu için daima şiddet normalmiş gibi geliyor (Ö. 4). Şiddet eğilimi var. Problem çıkarma, sınıf huzurunu bozmaya ĕgilimli ögrenciler. Kazanılması için çok yönlü ve toplu çalışma ve gayreti gerektirir (Ö. 12). Okulda cam kırma, diğer öğrencilere zorbalık etme, okulu kirletme vb. davranışları var (Ö. 13). Çoğunda uyumdan kaynaklanan sorunlar yaşadığı için sessiz durmaya çalışlyorlar. Bir kısmı ise her saniye arkadaşlarına ya lakap ya mimikleriyle tehdit ya da firsatını bulduğunda şiddetvari davranışlar sergiliyorlar.(Kendine özgüveni olanlarda genelde bu eğilim görülüyor) (Ö. 14). Okulda geldikleri yerlerdeki alışkanlıkları arttırarak devam ettiriyorlar. Kabadayılık edenler var, çete kurmaya çalışanlar var. Arkadaşlarına karşı sert ve kaba davranma, küfürlü konuşma vb. var (Ö. 16).

\section{6. İç Göçle Yer Değiştiren Öğrencilerin Ekonomik Sorunlarının Eğitime}

\section{Yansımaları}

Araştırma kapsamında görüşme yapılan okul yöneticileri ve öğretmenlere "İç göçle yer değiştiren öğrencilerin ekonomik sorunlarının eğitime yansımaları nasıldır?” sorusu sorulmuştur. Alınan cevaplar analiz edilerek öğretmenlerin bu konudaki görüşleri kategoriler halinde Tablo 5'de verilmiştir.

Tablo 5. İç Göçle Yer Değiştiren Öğrencilerin Ekonomik Sorunlarının Eğitime Yansımaları

\begin{tabular}{ll}
\hline Kodlar & $\boldsymbol{f}$ \\
\hline Olumsuz tepkiler ve duygular oluşturma & 8 \\
\hline Başarı, motivasyon düşüklüğü & 3 \\
\hline Eğitimi arka plana atma & 3 \\
\hline Eğitsel ihtiyaçların temin edilmemesi & 3 \\
\hline Toplam & $\mathbf{1 7}$ \\
\hline
\end{tabular}

Tablo 5'te görüldüğü gibi araştırmaya katılan öğretmenlerin tamamı göçle gelen öğrencilerin ekonomik sorunlarının eğitime yansımalarıyla ilgili olarak olumsuz durumlardan bahsetmişlerdir. Bu problemleri öğretmenler şu ifadelerle ortaya koymuşlardır: 
Maddi ihtiyaçlarının karşılanamaması motivasyon, güdülenme, değersizlik vb. gibi durumları ortaya çıkarmıştır (Ö.1). Ekonomik yetersizlik çok yoğun yaşandı̆̆ı için temel ihtiyaçlar karşılanamadiğından eğitime ilgisizlik şeklinde yansıyor (Ö. 3). Başarılarının düşmesine sebep oluyor (Ö. 16). Ekonomik yetersizlikler mutsuzluk, şevksizlik şeklinde eğitime ilgisizlik şeklinde yansıyor (Ö. 14). Öğrencilerin ekonomik sorunlart eğitime olumsuz şekilde yansımaktadır. Özellikle öncelikleri yaşam ve beslenme olduğundan eğitimi arka plana atmışlardır (Ö. 11). Kitap, defter veya test alamıyorlar. Klyafetleri ve ayakkabıları da çok kötü durumda. Bu durumda bir ögrenciden ve veliden eğitime yönelik ne beklenilebilir acaba? Bazen veliye de bir şey söyleyemiyoruz. Temel ihtiyaçlarını gideremeyen insanlar elbette eğitimi arka siralara atacaklar (Ö. 15).

\section{Sonuç, Tartışma ve Öneriler}

Bu araştırmada Diyarbakır il merkezinde iç göçle yer değiştiren öğrencilerin yaşadıkları eğitimsel sorunlar okul yöneticileri ve öğretmen görüşlerine dayalı olarak ortaya konulmuş ve bu sorunların çözümüne ilişkin öneriler geliştirilmiştir. Araştırmada elde edilen bazı önemli sonuçlar şu şekilde sıralanmıştır:

1. Öğretmenlerle yapılan görüşmeler sırasında öğretmenlerin hemen hemen hepsi iç göçle yer değiştiren öğrencilerin sınıf, okul ve mahallede uyum problemleri yaşadıklarını ifade etmişlerdir. Araştırmada yer alan katılımcıların ifadelerine göre, iç göçle gelen öğrencilerin sınıfta, okulda ve okul dışı ortamlarda uyum problemi yaşadıkları görülmektedir. Bu bulguya benzer şekilde Avcı, Koçoğlu ve Ekici (2013), Diyarbakır ili merkez ilçelerinde göçün eğitim ve eğitim yönetimi üzerine etkilerini incelemek üzere yaptığı araştırmalarında iç göçle yer değiştiren öğrencilerde karşılaşılan en yoğun problem uyum sorunu olduğunu ortaya koymuşlardır. Dilovası'nda yapılan ve göçün eğitime etkilerini ele alan bir başka araştırmada da okul yöneticilerinin çoğunluğu öğrenci velilerinin çevreye uyum sağlamakta zorlandığını ifade etmişlerdir ve çevreye uyum sağlamak için ailelerin birkaç nesil orada yaşaması gerektiğini vurgulamışlardır. Araştırmaya göre göçle gelen öğrenciler sınıfta çekingen ve sessiz, okulda ise daha çok saldırgan ve nezaketsiz davranışlar sergilemektedirler (Nar, 2008). Bu durumda iç göçle gelen öğrenciler için okullarda oryantasyon süreci etkin kılınmalıdır. Okula aidiyet duygusunu arttıracak etkinlikler düzenlenmeli, bu etkinliklerde öğrencilerin etkin katılımı sağlanmalıdır. Ayrıca okullarını paylaşmak zorunda kalan öğrencilerin ve velilerin de hassasiyetleri göz ardı edilmemelidir.

2. Öğretmenlerin görüşüne göre iç göçle yer değiştiren öğrencilerin çoğunluğunda akademik başarının düşük olduğu görülmektedir. Konuyla ilgili olarak Şama (2003) göç dalgasına maruz kalan illerde milli eğitimin temel amaçlarında bahsedilen ölçütlere layıkıyla uyulamadığını ve bu durumun da eğitim sürecinde olumsuzlukları doğurduğunu ifade etmektedir. Yine Diyarbakır ilinde yapılan bir başka araştırmaya göre göç ile gelen 
öğrencilerden kaynaklanan problemler ele alındığında, okul yöneticilerinin çoğunluğuna göre en yoğun problem öğrencilerdeki uyum sorunu ve bu sorunlardan kaynaklı zamanla ortaya çıkan davranış bozuklukları ve başarısızlıktır (Avcı, Koçoğlu ve Ekici, 2013). Bu bağlamda akranlarına göre geride kalan öğrencilere takviye kurslarla destek sağlanması ya da telafi derslerinin verilmesi gerekmektedir. Burada öğrencilerin akademik olarak ilerleme durumlarının düzenli olarak raporlanması ve takip edilmesi önemlidir.

3. Araştırmada öğretmen görüşlerine göre velilerin temel ihtiyaçlarını (fiziki, barınma, güvenlik vs.) karşılamakta zorluk çekiyor olmaları çocukların eğitimiyle ilgilenmelerine engel olduğu sonucuna ulaşılmıştır. Pazarlığlu, (2007) göç eden ailelerin gittikleri yerlerde huzuru umut ederken maddi manevi birçok külfetle yüz yüze geldiğini ve bu durumun sosyo ekonomik düzeyi derinden etkilediğini ifade etmektedir. Dolayısıyla ailelerin çocuğun eğitimiyle ilgilenmesi öncüller sırasına girememektedir. Babaların çalışıyor ya da iş arıyor olmasından dolayı çocuğun eğitimiyle daha çok annelerin ilgilenmesine karşın annelerin okuryazarlık düzeyi çok düşüktür. Özkan ve Tösten'in (2011) Diyarbakır merkez ilçelerinde yapmış olduğu çalışmada anne babaların eğitim düzeyinin çok düşük olduğu görülmektedir. Garipağaoğlu, (2001) ise göç eden nüfusun eğitim profilinin genellikle düşük olduğunu ifade etmektedir. Bundan dolayı göçle yer değiştiren öğrencilerin annelerinin eğitimine önem verilmeli, gerekirse maddi teşviklerle okullarda anne eğitimine yönelik seminerler düzenlenmelidir.

4. Öğretmen görüşlerine göre iç göçle gelen öğrencilerin okullarda şiddet eğilimi gösterdikleri ortaya konulmuştur. Öğrencilerin yakın yaşam alanlarında görülen şiddet içerikli hatıralar çocukların dünyasını şekillendirmektedir. Makro düzeyde bakıldığında ise Cömertler ve Kar'ın (2007) suç oranlarının belirleyicilerini ortaya koyduğu yatay kesit analizi çalışması konuya 1şık tutmaktadır. Çalışmaya göre göçün suç oranlarıyla pozitif yönde ilişkili olduğu görülmüştür. Yine aynı çalışmada göçün önlenmesinde bölgesel kalkınma planlarının gerektiği vurgulanmıştır. Bu durumda okul bünyesinde spor ve sanat etkinlikleri düzenlenerek göçle gelen öğrencilere yeni uğraşlar (hobiler) ve hedefler sunularak olumsuz tutum ve davranışlardan uzaklaşmaları sağlanmalıdır.

5. Öğretmenler, iç göçle gelen öğrencilerin maddi problemlerinin olduğunu, bu problemlerin beraberinde birçok olumsuzluklara sebep olduğunu ifade etmişlerdir. Benzer şekilde Bahar ve Korkmaz-Bingöl, (2010) göçün maddi olumsuzlukları gidermekten çok yaydığını ifade etmektedir. Karakuş’un, (2006) çalışmasında da çocukların eğitim-öğretime dair gereksinimlerinin karşılanamamasının başta ekonomik nedenlere dayandığı anlaşılmaktadır. Gerek hükümetin gerekse yerel yönetimler ekonomik desteklerle ilgili 
çalışmalara destek vererek milli eğitim müdürlüklerinin bu konudaki etkinliği arttırılmalıdır (URL-1, 2016).

\section{Makalenin Bilimdeki Konumu}

Eğitim Bilimleri/Eğitim Yönetimi, Teftişi, Planlaması ve Ekonomisi

\section{Makalenin Bilimdeki Özgünlüğü}

Eğitim öğretim sürecinde zaman zaman yaşanan iç göçün neden olduğu eğitimsel sorunların doğru olarak tespit edilmesi gerekmektedir. Bunun için de okul yöneticileri ve öğretmenleri başta olmak üzere okulun tüm bileşenlerinin gözlemleri oldukça önemlidir. Uygulamanın içinde olan ve bu sorunlarla sıkça karşılaşan öğretmen ve okul yöneticilerinin görüşlerine başvurularak sorunların doğru ve tam olarak saptanması gerekmektedir. Böylece bilimsel çözüm önerileri ortaya konularak eğitim sürecinde oluşabilecek aksaklıkların önüne geçilebilir. İşte bu araştırma, Diyarbakır ilinde yaşanmış iç göçe maruz kalan öğrencilerin yaşadıkları eğitimsel sorunları ve buna yönelik çözüm önerilerini ortaya koyma bakımından özgünlük taşımaktadır.

\section{Kaynakça}

Akokpari, J. K. (1998) The state, refugees and migration in sub-saharan Africa. International Migration. 36(2), s. 211-234.

Aksoy, M. (2006). Doğu ve Güneydoğu Anadolu Bölgeleri’nde terörün neden ve sonuçları. International Journal of Human Sciences, 1(1).

Altunışık, R., Coşkun, R., Yıldırım, E. ve Bayraktaroğlu, S. (2001). Sosyal bilimlerde araştırma yöntemleri. Sakarya: Sakarya Kitabevi.

Avcı, Y. E., Koçoğlu, E. ve Ekici, Ö. (2013). Göçün eğitim ve eğitim yönetimine etkisine ilişkin okul yöneticilerinin görüşleri (Diyarbakır ili örneği). International Journal of Social Science. 6-2 s. 91-105.

Bahar, O. ve Korkmaz-Bingöl, F. (2010). Türkiye'de iç göç hareketlerinin istihdam ve işgücü piyasalarına etkileri. Süleyman Demirel Üniversitesi İktisadi ve İdari Bilimler Fakültesi Dergisi, 15(2).

Bülbül, S. ve Köse, A. (2010). Türkiye'de bölgelerarası iç göç hareketlerinin çok boyutlu ölçekleme yöntemi ile incelenmesi. İstanbul Üniversitesi İsletme Fakültesi Dergisi, 39(1), 75-94.

Cömertler, N. ve Kar, M. (2007). Türkiye'de suç oranının sosyo-ekonomik belirleyicileri: Yatay kesit analizi. Ankara Üniversitesi SBF Dergisi, 62(02), 037-057. 
Erkan R. ve Bağlı M. (2005). Göç ve yoksulluk alanlarında kentle bütünleşme eğilimi: Diyarbakır örneği. Hacettepe Üniversitesi Edebiyat Fakültesi Dergisi, Cilt: 22, Sayı: 1, Haziran, s. 105-124.

Garipağaoğlu, N. (2001). Türkiye'de göç alan illere yönelen nüfusun eğitim durumu. Marmara Coğrafya Dergisi, 2, 3.

Gedikoğlu, T. (2005). Avrupa Birliği sürecinde Türk Eğitim Sistemi: Sorunlar ve çözüm önerileri. Mersin Üniversitesi Eğitim Fakültesi Dergisi, 1(1).

Gür, T. H. ve Ural, E. (2004). Türkiye'de kentlere göçün nedenleri. Hacettepe Üniversitesi İktisadi ve İdari Bilimler Fakültesi Dergisi, 22(1).

Gürel, S. (2001). “21. Yüzyıl karşısında kent ve insan.” Türkiye’de göç ve bütünleşme sorunsalı (Ed: Gümüşoğlu, F.). Bağlam Yayınları.

Güreşci, E. (2010). Türkiye'de kentten-köye göç olgusu. Doğuş Üniversitesi Dergisi, 11(1), 7786.

Karakuş, E. (2006). Göç olgusu ve eğitime olumsuz etkileri (Sultanbeyli örneği). Yüksek Lisans Tezi. Sakarya Üniversitesi Sosyal Bilimler Enstitüsü.

Miles, M. B. ve Huberman, A. M. (1994). Qualitative Data Analysis. London: Sage Publication. 2. Edition.

Nar, B. (2008). Göçün eğitime ve eğitim yönetimine etkileri (Dilovası örneği). Sakarya Üniversitesi Sosyal Bilimler Enstitüsü. Yüksek Lisans Tezi.

Özkan, F. ve Tösten, R. (2011). İlköğretim I. kademe öğrencilere dini değerlerin kazandırılmasında ailenin etkisi: Diyarbakır ili örneği. Eskişehir Osmangazi Üniversitesi Değerler Eğitimi Sempozyumu (26-28 Ekim), Eskişehir.

Pazarlığlu, M. V. (2007). İzmir örneğinde iç göçün ekonometrik analizi. Yönetim ve Ekonomi, 14, 1.

Richmond, A. H. (1994). Global apartheid: Refugees, racism and the new world order. Oxford University Press, Toronto.

Şama, E. (2003). Öğretmen adaylarının çevre sorunlarına yönelik tutumları. Gazi Üniversitesi Gazi Eğitim Fakültesi Dergisi, Cilt 23, Sayı 2, 99-110

URL-1. (2016). Habertürk Gazetesi. http://www.haberturk.com/ gundem/ haber/ 1170524davutoglu -teror- magdurlarina -destek -paketini -acikladi E.T: 30.05.2016.

Üçdoğruk, Ş. (2013). İzmir'deki iç göç hareketinin çok durumlu logit teknikle incelenmesi. Dokuz Eylül Üniversitesi İktisadi ve İdari Bilimler Fakültesi Dergisi, 17. 
Yıldırım, A. ve Şimşek, H. (2005). Sosyal bilimlerde nitel araştırma yöntemleri. Ankara: Seçkin Yayınevi.

\section{Summary}

\section{Purpose}

The aim of this study is to identify the problems of the students in the schools whose population has being increased because of the internal migration in the central districts of Diyarbakır province. The schools located in the central districts of Diyarbakır were identified according to the criteria that whose population has being increased because of the internal migration. The opinions of the administrators and teachers in these sample schools were consulted. One of the other purposes of this research is to make suggestions related to this issue for the teachers and administrators who face this kind of problems in the educational process.

\section{Method}

This research is conducted by using qualitative research design. Therefore, in order to achieve the main objective of the research, the interviews were made to collect detailed data from the teachers and administrators who are in the public schools whose number of students increased dramatically because of the internal migration. For the interviews, semi- structured interview forms were used. The questions in the interview forms were determined first by a preliminary discussion with the teachers and administrators then were revised according to the views of academicians. The forms were applied to two school principals, two vice-principals and 13 teachers. The data was analyzed by descriptive analysis technique and the educational problems were detected according to the views of teachers.

\section{Findings}

At the end of the research, the students who replaced their schools because of internal migration were found to have adaptation problems, having low academic success, having unconcerned parents, having violence tendencies and having financial problems. Some suggestions were set forth for the solution of these problems.

\section{Results and Discussion}

In our country, a migration has been experienced from rural areas to urban centers, from developed regions towards less developed regions since the 1950s. In addition, in recent years intensive internal migration movements have emerged inside the city centers. In particular, the 
terrorism problem in Eastern and Southeastern Anatolia Regions is an important factor that triggers this situation. Located in the Southeastern Anatolia Region and socio-politically an important province, Diyarbakır, recently exposed to a serious internal migration because of increased terrorist incidents and curfews declared in the district of Sur. This internal migration is not an ordinary replace movement but its negative effects are shown in economic, social, cultural and educational fields. Education is a process and unexpected events that occur in this process can be quite destructive in the educational process. The effects of a negative situation occurring in education can manifest itself in time and in different ways. When considering the problems occurring in the fields of education are rooted and fluctuates day by day. Therefore presenting solutions and timely detection these problems by stakeholders in education is very important for a lasting and effective solution. Diyarbakir province was affected too much from the terrorism, which started in 2016 and was experienced in several neighborhoods in the city. Citizens residing in neighborhoods, where these events often repeated were forced to leave the region. Internal migration, which became compulsory with the announcement of the curfew, reduced the number of students in many schools as well as it increased the number of students in many schools in the city center.

Schools that took the register of the children of families who were displaced by internal migration were obliged to take necessary measures to prevent the disruption of education in the face of this unexpected population growth. Otherwise, if they fail to integrate the new students to the education, the current training activities were to be also damaged. For this purpose, in the determination of the educational problems caused by intensive internal migration in Diyarbakır, the observations of all components of the schools especially school administrators and teachers who are in the application are very important. By referring to the opinions of the teachers and administrators who encounter these problems frequently, the problems can be detected correctly, scientific solutions can be made, and therefore this is thought to be an effective way of preventing the problems in the process of education.

The internal migration was found to have an efficient role on the students' educational life. These students are having adaptation problems because of this process. The students are also having low academic success, unconcerned parents, violence tendencies and financial problems. That means the educational authorities should take urgent and necessary precautions as soon as possible. The governors should plan the educational background of the school before registering the immigrant students. 